\title{
Toward Fine Mapping of the Tomato Yellow Leaf Curl Virus Resistance Gene Ty-2 on Chromosome 11 of Tomato
}

\author{
Yuanfu Ji, John W. Scott ${ }^{1}$, and David J. Schuster \\ Gulf Coast Research and Education Center, University of Florida, 14625 CR \\ 672, Wimauma, FL 33598
}

Additional index words. Lycopersicon esculentum, Solanum habrociates, Solanum lycopersicum, begomovirus, disease resistance, marker-assisted selection

\begin{abstract}
The whitefly-transmitted Tomato yellow leaf curl virus (TYLCV) is a major pathogen of tomatoes grown in tropical and subtropical regions of the world. Several genes of different origins conferring resistance to TYLCV have been introgressed to the cultivated tomato (Solanum lycopersicum), including the single dominant gene, Ty-2, that originated from $S$. habrochiates and was previously mapped to a 19-cM region on the long arm of chromosome 11 delimited by restriction fragment length polymorphism markers TG36 and TG393. In the present study, we confirmed the dominant inheritance of the Ty-2 gene from TYLCV evaluation and molecular marker analysis of an $F_{2}$ segregating population derived from a commercial hybrid that carries the $T y$ - 2 gene. Evaluating recombinants recovered from the $F_{2}$ progeny for TYLCV resistance localized the $T y-2$ gene to a marker interval of $5.5 \mathrm{cM}$ between C2_At1g07960 (82.5 cM) and C2_At4g32930 $(88 \mathrm{cM})$. Additional recombinants were identified for the target region carrying the $T y-2$ gene. TYLCV evaluation of the progeny from these recombinants further delimited the $T y$-2 gene to a 4.5-cM interval between C2_At1g07960 (82.5 cM) and cLEN-11-F24 (87 cM). The smaller introgressions no longer include the fusarium wilt race 2 resistance locus (I-2), which should facilitate combining the two resistance genes in cis configuration. The polymerase chain reaction-based markers developed from the present study can be used to precisely monitor the introgression of the $T y-2$ gene, thus offering the opportunity to pyramid TYLCV resistance genes from different sources as well as resistance genes for other pathogens into elite tomato cultivars.
\end{abstract}

Tomato yellow leaf curl virus (TYLCV) was the first monopartite begomovirus whose genome was characterized (Navot et al., 1991). TYLCV infects a wide range of host plants, including tomato, pepper, potato, tobacco, and numerous dicot species (Polston and Anderson, 1997). Disease symptoms in tomato (Solanum lycopersicum, formerly Lycopersicon esculentum) include leaf curling and yellowing and plant stunting. TYLCV is transmitted by the sweetpotato whitefly, Bemisia tabaci (Genn.), also known as the silverleaf whitefly $(B$. argentifollii Bellows \& Perring), and has caused serious losses to tomato production in tropical and subtropical regions of the world ( $\mathrm{Ji}$ et al., 2007b; Polston and Anderson, 1997). Entire crops are often lost if plants are infected in early growth stages (Pico et al., 1996). To date, TYLCV resistance has not been found in $S$. lycopersicum germplasm, but high

\footnotetext{
Received for publication 28 Jan. 2009. Accepted for publication 28 Feb. 2009.

This research was partially funded by grants from the Florida Tomato Committee and USDA NRI Grant \#2007-35300-18248 to JWS.

We thank Dolly Cummings, Cathy Provenzano and Rosa Ayala for technical assistance and plant maintenance; and Anne Kirkwood, Aaron Shurtleff, and Steve Kalb for assistance in virus inoculation. ${ }^{1}$ To whom reprint requests should be addressed; e-mail jwsc@ufl.edu.
}

levels of resistance were reported in several tomato wild species, including $S$. pimpinellifolium, S. peruvianum, S. chilense, S. habrochaites (formerly Lycopersicon hirsutum), and S. cheesmaniae ( $\mathrm{Ji}$ et al., 2007b; Pico et al., 1996; Scott, 2007; Vidavski, 2007). Early breeding efforts successfully transferred resistance genes from these wild species into cultivated tomato using traditional breeding approaches (Scott et al., 1996). The first such gene, $T y$-1, was introgressed into tomato from $S$. chilense accession LA1969 (Zamir et al., 1994). A second TYLCV resistance gene, $T y$-2, was introduced into tomato from $S$. habrochaites (Hanson et al., 2000; Kalloo and Banerjee, 1990). Two additional TYLCV resistance genes, $T y-3$ and $T y$ 4, were recently discovered in $S$. chilense accessions and mapped to chromosomes 6 and 3, respectively (Ji et al., 2007a, 2008).

The $T y-2$ gene is one of the major sources of TYLCV resistance used in tomato breeding programs, but it is not effective against some TYLCV strains in some regions in the world (Mejía et al., 2005). The source line for this gene, H24, was developed from $S$. habrochiates f. glabratum accession 'B6013' (Kalloo and Banerjee, 1990) and contains an introgression spanning beyond a marker interval from TG36 (map position $84 \mathrm{cM}$ ) to TG393 $(103 \mathrm{cM})$, a distance of at least 19 cM (Hanson et al., 2000). Breeding lines with a shorter introgression missing the segment between TG26 (92 cM) and TG393 still displayed the same level of resistance to TYLCV as lines carrying the full H24 introgression; therefore, the $T y$-2 gene was located in the vicinity of TG36, and the shorter introgression carrying the $T y$ - 2 gene spanned a region at least from TG36 (inclusive) to TG26 (exclusive), a distance of $\approx 8 \mathrm{cM}$ (Hanson et al., 2006; Ji et al., 2007b). The objective of the present study was to precisely identify the length and marker interval of the $S$. habrochiates introgression with more molecular markers in the target region and further delimit the $T y-2$ gene to a smaller marker interval and develop lines with shorter introgressions that still carry the $T y$-2 gene.

\section{Materials and Methods}

Plant materials. The $\mathrm{F}_{2}$ progeny from a Heinz $\mathrm{F}_{1}$ hybrid $\mathrm{H} 9205$ with resistance from $\mathrm{H} 24$ was used to characterize the inheritance of the $T y$ - 2 gene during Spring 2007 (Fig. 1). Three recombinant plants were identified by molecular marker analysis, i.e., plant Nos. 82,108 , and 134 , from a population of $206 \mathrm{~F}_{2}$ progeny. No mature seeds could be harvested from the susceptible plant No. 108. In Fall $2007, F_{3}$ progeny from the other two recombinant plants (Nos. 82 and 134) were evaluated in the field for TYLCV resistance to map the $T y-2$ gene to a smaller introgression region. Two recombinant plants (Nos. 3 and 96) were recovered from the segregating progeny of plant No. 134 in the $\mathrm{F}_{3}$ generation. Meanwhile, seeds from another three plants (Nos. 8, 36, and 177) from the Spring $2007 \mathrm{~F}_{2}$ population that were heterozygous for the whole $S$. habrochiates introgression, as were genotyped with molecular markers, were sown and grown in the greenhouse in Fall 2007 to identify more recombinants in the introgression. Among the $1472 \mathrm{~F}_{3}$ seedlings, 12 recombinants were identified with molecular markers in the target region carrying the Ty-2 gene, transplanted to $3.8-\mathrm{L}$ pots, and grown to maturity in the greenhouse. Seeds were harvested from the recombinant plants grown in the greenhouse (the $12 \mathrm{~F}_{3}$ s to the left in Fig. 1) and in the field (the two $\mathrm{F}_{3} \mathrm{~s}$ to the right in Fig. 1). In Spring 2008, 24 plants from each of the $14 \mathrm{~F}_{4}$ recombinants (E953 to E966) were inoculated with whiteflies viruliferous for TYLCV (described subsequently) and evaluated in the field for TYLCV resistance to further delimit the $T y-2$ gene to a smaller interval. The commercial hybrid, 'TYQUEEN', carrying the $T y$-2 gene (kindly provided by Green Seeds Ltd., Ho Chi Minh City, Vietnam) was used as a resistant control in Spring 2008, and 'Horizon' was used as a susceptible control in all seasons. In addition, 'Horizon' and two S. habrochiates accessions, LA0386 and LA1777, were included as control genotypes in all polymerase chain reaction (PCR) experiments to develop polymorphic molecular markers. The wild $S$. habrochiates accessions were obtained from the Tomato Genetics Resource Center at UC-Davis, Davis, CA. 
Generation

F1

F2

F3

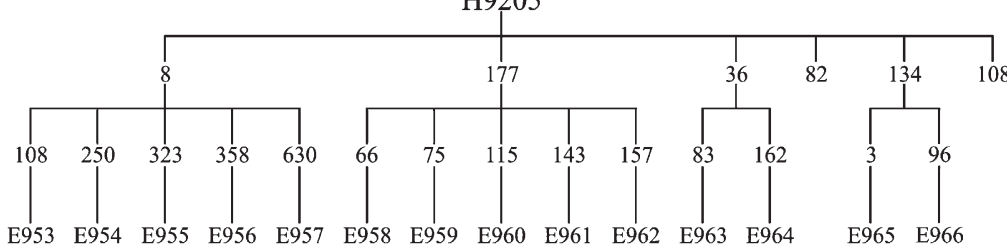

F4

Fig. 1. Pedigree for the selected lines and plants derived from $\mathrm{F}_{1} \mathrm{H} 9205$ carrying the $T y-2$ gene. $\mathrm{F}_{2}$ plant Nos. 8, 36, and 177 were heterozygous for the full $S$. habrochiates introgression between C2_At1g07960 and TG105A; F 2 plant Nos. 82, 108, and 134 were recombinants (see Table 4 for detail).

Inoculation and disease evaluation. Plants were inoculated with whiteflies from a colony that was viruliferous for TYLCV and subsequently assessed for disease severity according to the method described by Griffiths and Scott (2001) with some modifications. Briefly, seedlings 3 weeks past the cotyledon stage (two to three leaves) were exposed to viruliferous whiteflies for 2 weeks. After inoculation, the whiteflies were killed and the plants transplanted to field plots. For the Spring 2007 experiment, the plants were first rated for TYLCV disease severity at $\approx 30 \mathrm{~d}$ after exposure to whiteflies. Another two ratings were taken at 2-week intervals. Only one rating was taken at $\approx 30$ $\mathrm{d}$ after exposure to whiteflies for the plants in Fall 2007 and Spring 2008 experiments. The rating scale was from 0 to 4 as documented by Scott et al. (1996), where $0=$ no disease symptoms, 1 = slight symptoms visible only on close inspection, 2 = symptoms apparent at a distance of two-thirds $m$ from the plant, $3=$ severe symptoms over entire plant, and $4=$ severe symptoms and stunting over entire plant. Intermediate scores $(0.5,1.5$, and so on) were incorporated to allow for more precise disease severity ratings.

Polymerase chain reaction analysis. Total genomic DNA was isolated from young leaves of the plants 3 weeks after transplanting to the field or seedlings 2 to 3 weeks after transplanting to the speeding trays as described previously (Fulton et al., 1995). All markers used in this study are PCR-based, including sequence-characterized amplified region (SCAR) markers and cleaved amplified polymorphic sequence (CAPS) markers taken from either the public domain or designed from public sequences. The PCR amplification reaction contained $0.4 \mathrm{mM}$ each of dNTPs, $0.4 \mu \mathrm{M}$ each forward and reverse primer, 0.5 units of Taq polymerase, $100 \mathrm{mM}$ Tris- $\mathrm{HCl}(\mathrm{pH} 9.1), 500 \mathrm{mM} \mathrm{KCl}, 2 \mathrm{mM}$ $\mathrm{MgCl}_{2}, 1 \%$ Triton $\mathrm{X}-100$, and $\approx 15 \mathrm{ng}$ DNA template in a reaction volume of $20 \mu \mathrm{L}$. All PCR reactions were performed in a PerkinElmer GeneAmp PCR 9700 Thermal Cycler (PerkinElmer Inc., Waltham, WA) for 34 cycles, each consisting of $30 \mathrm{~s}$ at $94{ }^{\circ} \mathrm{C}, 45 \mathrm{~s}$ at varied annealing temperatures (in most cases $55^{\circ} \mathrm{C}$ ), and $1 \mathrm{~min}$ at $72{ }^{\circ} \mathrm{C}$. The PCR products were separated on a $1.5 \%$ agarose gel stained with ethidium bromide and visualized under ultraviolet (ultraviolet) light. For CAPS markers, $\approx 4 \mu \mathrm{L}$ of PCR product was digested with 1.5 units of the appropriate restriction enzyme in a total volume of $10 \mu \mathrm{L}$ for 30 to 60 min. Buffers and temperature were as described by the manufacturers. Digested DNA fragments were separated on $1.5 \%$ agarose gel and visualized under ultraviolet light.

Statistical analysis. A $\chi^{2}$ goodness-of-fit test was used to assess the segregation ratios of the SCAR and CAPS markers for conformity with the expected ratio of $1: 2: 1$ and also the segregation ratio of resistant versus susceptible $\mathrm{F}_{2}$ plants for conformity with the expected ratio of $3: 1$. The marker genotypes were tested for significant associations with disease severity using SAS general linear model analysis (SAS Institute, Cary, NC). Duncan's multiple range test was used to analyze the TYLCV resistance of different genotypes of the $\mathrm{F}_{2}$ progeny.

\section{Results}

S. habrochiates introgression in the Tomato yellow leaf curl virus-resistant $F_{1}$ hybrid. SCAR and CAPS markers (Table 1) converted from RFLP, EST and BAC clone sequences near the $T y$ - 2 region on chromosome 11 were used to identify the introgression in the TYLCV-resistant $F_{1}$ hybrid H9205. The introgression in H9205 spanned the marker interval between C2_At1g07960 $(82.5 \mathrm{cM})$ and TG105A $(90 \mathrm{cM}), \approx 7.5 \mathrm{cM}$ in length. This introgression was much shorter than the introgressed segment in the source line H24, which spans the region from TG393 to TG36, a distance of at least $19 \mathrm{cM}$ (Fig. 2).

Inheritance of Ty-2. Evaluation of TYLCV disease severity for $206 \mathrm{~F}_{2}$ plants from $\mathrm{H} 9205$ had an acceptable fit to a 3:1 ratio of resistant versus susceptible plants, supporting control of resistance by a single dominant gene (Table 2 ). All susceptible plants showed severe disease symptoms, including severe stunting and foliar yellowing and curling. No symptoms were observed on almost all (146 of 151) of the resistant plants. Five plants displayed moderate symptoms such as light foliar yellowing and curling and slight plant stunting with disease severity ratings of 1.5 or 2 . Molecular marker analysis indicated that one of these five plants was homozygous for the introgression and the other four were heterozygous. Further TYLCV evaluation showed that all progeny from the homozygous plant were completely resistant, whereas progeny from the four heterozygous plants segregated for TYLCV resistance (data not shown)

After $\approx 8$ weeks of exposure to viruliferous whiteflies, approximately one-third of the resistant plants were still symptomless and the remaining two-thirds developed moderate disease symptoms, but the disease severities were still rated 2 or lower except for one plant, which had a disease severity of 2.5 (data not shown). Molecular marker analysis indicated this plant was homozygous for the introgression. Further TYLCV evaluation showed that all the progeny from this plant were completely resistant (data not shown). These results indicated analysis using the last rating had the same interpretation of the resistance, i.e., an acceptable fit to a 3:1 ratio of resistant versus susceptible plants, as using the first rating. Therefore, only one rating was taken for each plant at $\approx 30 \mathrm{~d}$ after exposure to whiteflies for the experiments thereafter.

Plants either heterozygous or homozygous for the $S$. habrochiates introgression carrying the $T y-2$ gene showed high levels of resistance to TYLCV, ranging from 0 to 2 or 0 to 2.5 , respectively, although the disease severity for the heterozygotes, with a mean disease severity of 0.59 , was significantly lower than that of the homozygotes with a mean disease severity of 0.85 (Table 3 ). In addition, heterozygous $F_{2}$ plants showed more vigorous growth and produced more mature fruits than the homozygotes (data not shown). These findings suggested that the resistance in the heterozygotes was effective at the late stage of plant growth and that there may have been some detrimental effects when the introgressed region was homozygous.

Molecular marker analysis of the $F_{2}$ progeny from H9205. Molecular marker analysis of the $\mathrm{F}_{2}$ plants showed that all the plants with a disease severity of 2.5 or lower were either homozygous or heterozygous for the $S$. habrochaites introgression carrying the $T y$-2 gene, whereas all plants with disease severity of 3 and above were devoid of the introgression except one plant, No. 108 (Table 4). This plant was a recombinant and heterozygous for a short introgression between Hba78A16T7 (89.7 cM) and TG105A (90 $\mathrm{cM})$. The disease symptoms were so severe for this plant (a disease severity of 4 ) that no mature seeds could be harvested from this plant. These findings indicated that the $T y-2$ gene is located in the top part of the introgression between C2_At1g07960 $(82.5 \mathrm{cM})$ and C2_At5g25760 (89.5 cM), a distance of $7 \mathrm{cM}$. To further map the location of the $T y$-2 gene, we evaluated the progeny from the two resistant recombinants identified from the same $F_{2}$ population for TYLCV resistance. All of the 126 progeny from recombinant plant No. 82 were resistant, whereas the 113 progeny from plant No. 134 segregated for the TYLCV resistance. This segregation along with marker analysis suggested $T y-2$ is located in the marker interval between C2_At1g07960 (82.5 cM) and C2_At4g32930 (88 cM), a distance of $5.5 \mathrm{cM}$. All resistant plants were either 


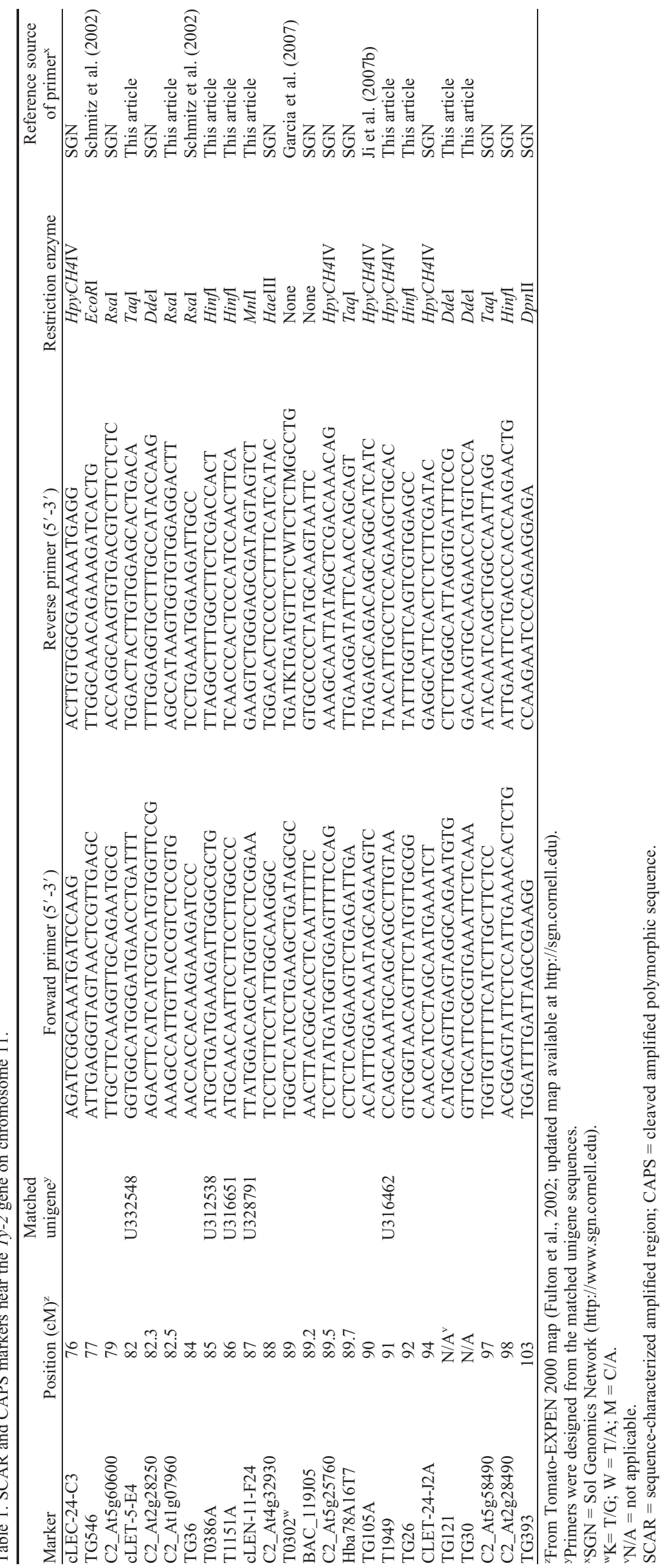

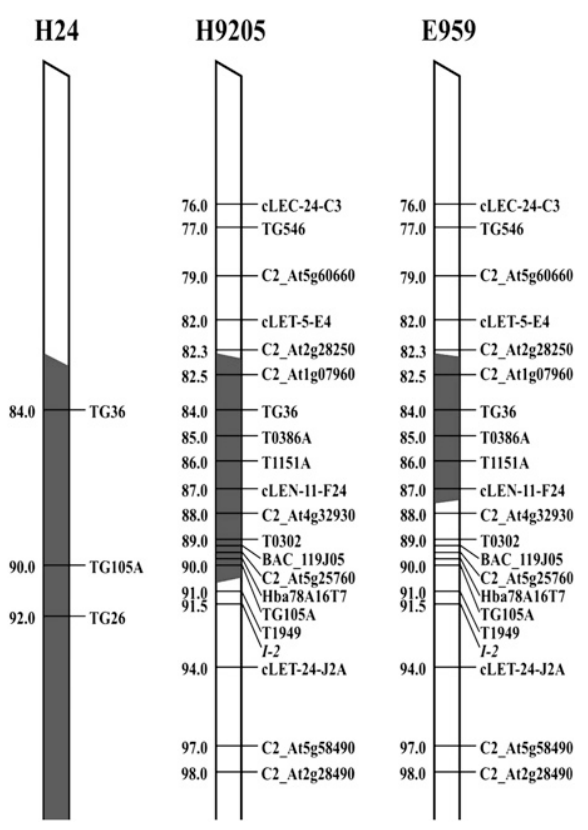

Fig. 2. Location of $S$. habrochiates introgressions in line H24 (left; adapted from Hanson et al., 2000), $\mathrm{F}_{1}$ hybrid $\mathrm{H} 9205$ (middle), and E959, an $\mathrm{F}_{3}$ line derived from $\mathrm{H} 9205$ (right), which carry the $T y$-2 gene conferring resistance to Tomato yellow leaf curl viruses on chromosome 11 of tomato. Shaded regions represent introgressions from $S$. habrochiates. The numbers on the left of each map represent the map locations (centiMorgans) for the markers in the EXPEN 2000 map published in the Sol Genomics Network (http://www.sgn.cornell.edu). All markers are polymerase chain reaction-based, including sequence-characterized amplified region (SCAR) marker and cleaved amplified polymorphic sequence (CAPS) markers taken from either the public domain or designed from public sequences. The markers in nonintrogression regions are not drawn to scale.

homozygous or heterozygous for the introgression, whereas all susceptible plants were devoid of the introgression, supporting the dominant inheritance of $T y-2$ gene. Two recombinants were recovered from the segregating progeny of plant No. 134 in the $F_{3}$ generation (Fig. 1; Table 4). The progeny of these two recombinants were included in the follow-up experiments to construct a highresolution map of the $T y-2$ gene (Table 5). All molecular markers associated with the introgression showed a significant association with TYLCV resistance (data not shown).

High-resolution map of the Ty-2 gene with more recombinants in the target region. Twelve additional recombinants were identified from a population of 1472 progeny derived from the three $\mathrm{F}_{2}$ plants heterozygous for the target introgression region carrying the $T y$-2 gene, i.e., from C2_At1g07960 (82.5 $\mathrm{cM})$ to T0302 (89 cM). Marker T0302 was used instead of C2_At4g32930 (88 cM) because T0302 is a robust SCAR marker; therefore, it was more time- and cost-efficient, because enzyme digestion of PCR products was not necessary. Twenty-four plants from each of the 12 recombinants as 
Table 2. A $\chi^{2}$ test for the segregation of Tomato yellow leaf curl virus resistance among the $\mathrm{F}_{2}$ progeny derived from a $\mathrm{F}_{1}$ hybrid $\mathrm{H} 9205$ that possesses the $T y-2$ gene.

\begin{tabular}{|c|c|c|c|c|c|c|c|c|c|}
\hline \multirow[b]{2}{*}{ Genotype } & \multirow[b]{2}{*}{ Total plants } & \multicolumn{6}{|c|}{ Disease severity $^{z}$} & \multirow[b]{2}{*}{$\chi^{2}(3: 1)$} & \multirow[b]{2}{*}{$P$} \\
\hline & & 0 & 1.5 & 2 & 3 & 3.5 & 4 & & \\
\hline (H9205)-BK & 206 & 146 & 2 & 3 & 1 & 2 & 52 & 0.32 & $0.9-0.5$ \\
\hline
\end{tabular}

zPlants noted as 0 to 2 were considered resistant, whereas plants greater than 2 were susceptible.

Table 3. Disease [Tomato yellow leaf curl virus (TYLCV)] severity of the $\mathrm{F}_{2}$ plants derived from $\mathrm{F}_{1}$ hybrid $\mathrm{H} 9205$ as grouped by their genotypes for a molecular marker linked to the Ty-2 gene.

\begin{tabular}{lcll}
\hline & \multirow{2}{*}{$\begin{array}{c}\text { Number } \\
\text { observed }\end{array}$} & \multicolumn{2}{c}{ Disease severity } \\
\cline { 3 - 4 } C2_At1g07960 & Mean & Range \\
\hline $\mathrm{R}$ & 55 & $0.85 \mathrm{~b}^{\mathrm{x}}$ & $0-2.5$ \\
$\mathrm{H}$ & 96 & $0.59 \mathrm{a}$ & $0-2.0$ \\
$\mathrm{~S}$ & 55 & $3.95 \mathrm{c}$ & $3-4$ \\
Total & 206 & 1.56 & $0-4$ \\
\hline
\end{tabular}

${ }^{\mathrm{z}} \mathrm{R}=$ homozygous for the $S$. habrochiates allele; $\mathrm{S}=$ homozygous for the $S$. lycopersicum allele; $\mathrm{H}=$ heterozygous.

${ }^{\text {y }}$ The last rating taken after $\approx 8$ weeks of exposure to viruliferous whiteflies carrying TYLCV.

${ }^{\mathrm{x}}$ Means in column with the same letter are not significantly different $(P \leq 0.05$, Duncan's multiple range test)

well as the two recombinants mentioned previously were evaluated for TYLCV resistance in Spring 2008 (Table 5). Progeny from genotypes with introgressions devoid of the marker interval from C2_At1g07960 (82.5 cM) to cLEN-11-F24 (87 cM) were susceptible, whereas progeny from genotypes homozygous or heterozygous for the same marker interval were resistant or segregating for the TYLCV resistance, respectively. On the other hand, TYLCV resistance was not linked to the introgression region spanning the marker C2_At4g32930 (88 cM) and beyond toward the telomeric end. These findings suggested that $T y-2$ is located between markers C2_At1g07960 (82.5 cM) and cLEN-11-F24 (87 cM), an interval of 4.5 cM (Fig. 2).

\section{Discussion}

A major source of TYLCV resistance has been line $\mathrm{H} 24$ developed from $S$. habrochiates (Kalloo and Banerjee, 1990). The gene responsible for resistance in $\mathrm{H} 24, T y-2$, was originally mapped to the long arm of chromosome 11 in a region spanning beyond TG36 $(84 \mathrm{cM})$ and TG393 $(103 \mathrm{cM})$ on the centromere and telomeric end of the chromosome, respectively, a distance of at least 19 cM (Hanson et al., 2000). Later, Ty-2 was delimited to a smaller marker interval between TG36 and TG26 (92 cM), a distance of at least $8 \mathrm{cM}$, by molecular marker analysis of a set of lines carrying the full H24 introgression versus lines with a shorter introgression missing the segment between TG26 and TG393, both of which were resistant to TYLCV (Hanson et al., 2006). In the present study, we developed and used additional molecular markers to more precisely characterize the introgression region. Furthermore, more recombinants in the target region were identified from a larger population, which were used to map the $T y$-2 gene to a 4.5-cM interval between C2_Atlg07960 $(82.5 \mathrm{cM})$ and cLEN-11-F24 $(87 \mathrm{cM})$. In a previous report, the $T y-2$ gene was mapped to a position $\approx 5 \mathrm{cM}$ from tightly linked markers TG105A (90 cM) and T0302 (89 cM). However, the report failed to determine whether $T y-2$ lies on the telomeric or interstitial side of these PCR markers (Ji et al., 2007b). Our data indicated that the $T y-2$ gene lies on the interstitial side of these PCR markers. The combined data from the present study and the previous report indicate that the $T y-2$ gene is located in the vicinity of TG36 (84 $\mathrm{cM})$ and T0386A (85 cM). To confirm this inference as well as to further fine map the $T y$-2 gene, a much larger population would be necessary to identify recombinants in this region. Recombination was greatly suppressed in this region, because no recombinants were found in a population of $\approx 1600$ progeny.

It has been relatively easy to develop commercially acceptable hybrid cultivars using the $T y$ - 2 gene because it is a single dominant gene. After crossing the resistant lines homozygous for the $T y-2$ gene with an elite susceptible line, the resulting hybrids are usually as resistant as their resistant

Table 4. Molecular marker genotypes of three recombinant $F_{2}$ plants derived from $F_{1}$ hybrid $\mathrm{H} 9205$.

\begin{tabular}{|c|c|c|c|c|c|c|c|c|c|c|c|}
\hline $\begin{array}{l}\text { Plant } \\
\text { no. }\end{array}$ & $\begin{array}{c}\text { Disease } \\
\text { severity }^{z}\end{array}$ & $\begin{array}{l}\text { Marker } \\
\text { position } \\
(\mathrm{cM})\end{array}$ & $\begin{array}{c}\text { C2_At1g07960 } \\
82.5\end{array}$ & $\begin{array}{c}\text { TG36 } \\
84\end{array}$ & $\begin{array}{c}\text { T0386A } \\
85\end{array}$ & $\begin{array}{c}\text { C2_At4g32930 } \\
88\end{array}$ & $\begin{array}{l}\text { T0302 } \\
89\end{array}$ & $\begin{array}{c}\text { BAC_119J05 } \\
89.2\end{array}$ & $\begin{array}{c}\text { C2_At5g25760 } \\
89.5\end{array}$ & $\begin{array}{c}\text { Hba78A16T7 } \\
89.7\end{array}$ & $\begin{array}{l}\text { TG105A } \\
90\end{array}$ \\
\hline 82 & 0 & Genotype & $\mathrm{R}^{\mathrm{y}}$ & $\mathrm{R}$ & $\mathrm{R}$ & $\mathrm{R}$ & $\mathrm{H}$ & $\mathrm{H}$ & $\mathrm{H}$ & $\mathrm{H}$ & $\mathrm{H}$ \\
\hline 134 & 0 & & $\mathrm{H}$ & $\mathrm{H}$ & $\mathrm{H}$ & $\mathrm{H}$ & $\mathrm{H}$ & $\mathrm{H}$ & $\mathrm{H}$ & $\mathrm{R}$ & $\mathrm{R}$ \\
\hline
\end{tabular}

${ }^{2}$ Disease severity after $30 \mathrm{~d}$ of exposure to viruliferous whitefilies carrying Tomato yellow leaf curl virus.

${ }^{\mathrm{y}} \mathrm{R}=$ homozygous for the $S$. habrochiates allele; $\mathrm{S}=$ homozygous for the $S$. lycopersicum allele; $\mathrm{H}=$ heterozygous.

Table 5. Tomato yellow leaf curl virus (TYLCV) evaluation for progeny of 14 recombinant plants and molecular marker analysis in the target region for these 14 plants.

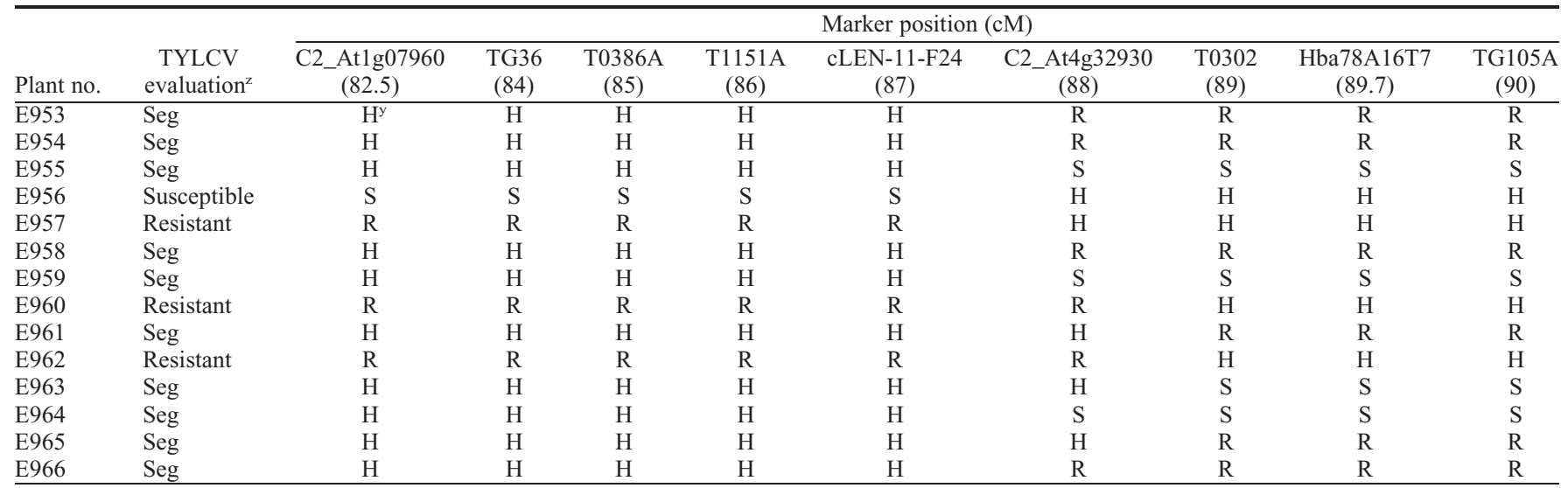

${ }^{\mathrm{z}}$ Twenty-four progeny from each recombinant plant were evaluated for TYLCV resistance. Resistant $=$ all plants resistant to TYLCV; susceptible $=$ all plants susceptible for TYLCV; Seg = segregating for TYLCV resistance.

${ }^{y} \mathrm{R}=$ homozygous for the $S$. habrochiates allele; $\mathrm{S}=$ homozygous for the $S$. lycopersicum allele; $\mathrm{H}=$ heterozygous. 
parent. However, the level of resistance achieved in such a manner may not hold under high inoculation pressure. Therefore, combining resistance genes of different origins in a single cultivar may be necessary to provide adequate levels of resistance. The PCR markers developed from the present study allow precise monitoring of the introgression of the $T y-2$ gene into elite breeding lines. Besides the $T y-2$ gene, other TYLCV resistance genes such as $T y-1, T y-3$, and $T y-4$ have also been mapped to different regions of the tomato genome with the assistance of tightly linked PCR-based molecular markers developed in other studies (de Castro et al., 2007; Ji et al., 2007a, 2008). These resistance genes originate from different wild tomato accessions and possess various modes of resistance with different or unknown effects on various begomovirus strains. PCR-based markers developed from current and previous studies can be used to effectively tag these TYLCV resistance genes and thus enhance selection efficiency (de Castro et al., 2007; Garcia et al., 2007; Ji et al., 2007a, 2008). In addition, these PCR-based markers can ease and expedite the process of pyramiding these resistance genes of various origins into a single elite genotype, thus improving the resistance to TYLCV as well as broadening the resistance against a wider range of begomoviruses (Vidavski, 2007).

In the vicinity of the $T y-2$ gene resides the I-2 gene, which confers resistance to race 2 of the fusarium wilt pathogen (Fusarium oxysporum f. sp. lycopersici) and was introgressed from the wild tomato species $S$. pimpinellifolium (Stall and Walter, 1965). $T y-2$ is tightly linked to fusarium wilt race 2 susceptibility and efforts from some tomato breeding programs to identify recombinants carrying both $T y-2$ and $I-2$ have been unsuccessful to date (Ji et al., 2007b). Our data indicated that the $T y-2$ gene, which was mapped to the marker interval between C2_At1g07960 (82.5 cM) and cLEN-11F24 $(87 \mathrm{cM})$, was at least $4.5 \mathrm{cM}$ away from the $I-2$ locus $(91.5 \mathrm{cM})$. The development of lines carrying $T y-2$ in a shorter introgressed segment without the $I-2$ region will make it easier to combine these two resistance genes in a single line. However, the ease of obtaining recombinants will also depend on the size of the $S$. pimpinellifolium introgression surrounding the $I-2$ gene. The $I-2$ introgressions for the four relevant lines tested by Scott et al. (2004) spanned the $T y$-2 region and would thus require a linkage break in these introgressions. Reduced recombination in introgressions from wild species has been reported (Canady et al., 2006; Ji et al., 2007a). Because both fusarium wilt and TYLCV are major constraints for tomato production in tropical regions, it would be advantageous for tomato to possess both fusarium wilt and TYLCV resistance (Hanson et al., 2000). Once they are linked in cis, they would remain linked in most lines developed from subsequent crosses.

\section{Literature Cited}

Canady, M.A., Y. Ji, and R.T. Chetelat. 2006. Homeologous recombination in Solanum lycopersicoides introgression lines of cultivated tomato. Genetics 174:1775-1788.

de Castro, A.P., J.M. Blanca, M.J. Díez, and F.N. Viñals. 2007. Identification of a CAPS marker tightly linked to the Tomato yellow leaf curl disease resistance gene $T y-1$ in tomato. Eur. J. Plant Pathol. 117:347-356.

Fulton, T.M., J. Chunwongse, and S.D. Tanksley. 1995. Microprep protocol for extraction of DNA from tomato and other herbaceous plants. Plant Mol. Biol. Rpt. 13:207-209.

Fulton, T.M., R. Van der Hoeven, N.T. Eannetta, and S.D. Tanksley. 2002. Identification, analysis, and utilization of conserved ortholog set markers for comparative genomics in higher plants. Plant Cell 14:1457-1467.

Garcia, B.E., E. Graham, K.S. Jensen, P. Hanson, L. Mejía, and D.P. Maxwell. 2007. Codominant SCAR marker for detection of the begomovirus-resistance $T y$-2 locus derived from Solanum habrochaites in tomato germplasm. Rep. Tomato Genet. Coop. 57:21-24.

Griffiths, P.D. and J.W. Scott. 2001. Inheritance and linkage of tomato mottle virus resistance genes derived from Lycopersicon chilense accession LA 1932. J. Amer. Soc. Hort. Sci. 126:462-467.

Hanson, P., S.K. Green, and G. Kuo. 2006. Ty-2, a gene on chromosome 11 conditioning geminivirus resistance in tomato. Rep. Tomato Genet. Coop. 56:17-18.

Hanson, P.M., D. Bernacchi, S. Green, S.D. Tanksley, V. Muniyappa, A.S. Padmaja, H. Chen, G. Kuo, D. Fang, and J. Chen. 2000. Mapping a wild tomato introgression associated with tomato yellow leaf curl virus resistance in a cultivated tomato line. J. Amer. Soc. Hort. Sci. 15:15-20.

Ji, Y., D.J. Schuster, and J.W. Scott. 2007a. Ty-3, a begomovirus resistance locus near the Tomato yellow leaf curl virus resistance locus $T y-1$ on chromosome 6 of tomato. Mol. Breed. 20:271284.

Ji, Y., J.W. Scott, P. Hanson, E. Graham, and D.P. Maxwell. 2007b. Sources of resistance, inheritance, and location of genetic loci conferring resistance to members of the tomato-infecting begomoviruses, p. 343-362. In: Czosnek, $\mathrm{H}$. (ed.). Tomato yellow leaf curl virus disease: Management, molecular biology, breeding for resistance. Kluwer, Dordrecht, The Netherlands.

Ji, Y., J.W. Scott, D.P. Maxwell, and D.J. Schuster. 2008. Ty-4, a tomato yellow leaf curl virus resistance gene on chromosome 3 of tomato. Rep. Tomato Genet. Coop. 58:29-31.
Kalloo, G. and M.K. Banerjee. 1990. Transfer of tomato leaf curl virus resistance from Lycopersicon hirsutum f. glabratum to L. esculentum. Plant Breed. 105:156-159.

Mejía, L., R.E. Teni, F. Vidavski, H. Czosnek, M. Lapidot, M.K. Nakhla, and D.P. Maxwell. 2005. Evaluation of tomato germplasm and selection of breeding lines for resistance to begomoviruses in Guatemala. Acta Hort. 695:251-256

Navot, N., E. Pichersky, M. Zeidan, D. Zamir, and H. Czosnek. 1991. Tomato yellow leaf curl virus: A whitefly-transmitted geminivirus with a single genomic component. Virology 185: 151-161.

Pico, B., M.J. Diez, and F. Nuez. 1996. Viral diseases causing the greatest economic losses to the tomato crop. 2. The tomato yellow leaf curl virus-A review. Sci. Hort. 67:151196.

Polston, J.E. and P.K. Anderson. 1997. The emergence of whitefly-transmitted geminiviruses in tomato in the western hemisphere. Plant Dis. 81:1358-1369.

Schmitz, G., E. Tillmann, F. Carriero, C. Fiore, F. Cellini, and K. Theres. 2002. The tomato blind gene encodes a MYB transcription factor that controls the formation of lateral meristems. Proc. Natl. Acad. Sci. USA 99: 1064-1069.

Scott, J.W. 2007. Breeding for resistance to viral pathogens, p. 447-474. In: Razdan, M.K. and A.K. Mattoo (eds.). Genetic improvement of solanaceous crops. Science Publisher, Inc., Enfield, NH.

Scott, J.W., H.A. Agrama, and J.P. Jones. 2004. RFLP-based analysis of recombination among resistance genes to fusarium wilt races 1,2 , and 3 in tomato. J. Amer. Soc. Hort. Sci. 129:394 400.

Scott, J.W., M.R. Stevens, J.H.M. Barten, C.R. Thome, J.E. Polston, D.J. Schuster, and C.A. Serra. 1996. Introgression of resistance to whitefly-transmitted geminiviruses from $\mathrm{Lyco}$ persicon chilense to tomato, p. 357-367. In: Gerling, D. and R.T. Mayer (eds.). Bemisia 1995: Taxonomy, biology, damage control, and management. Intercept Ltd., Andover, Hants, UK.

Stall, R.E. and J.M. Walter. 1965. Selection and inheritance of resistance in tomato to isolates of races 1 and 2 of Fusarium wilt organism. Phytopathology 55:1213-1215.

Vidavski, F.S. 2007. Exploitation of resistance genes found in wild tomato species to produce resistant cultivars; pile up of resistant genes, $p$. 363-372. In: Czosnek, H. (ed.). Tomato yellow leaf curl virus disease: Management, molecular biology, breeding for resistance. Kluwer, Dordrecht, The Netherlands.

Zamir, D., I. Eksteinmichelson, Y. Zakay, N. Navot, M. Zeidan, M. Sarfatti, Y. Eshed, E. Harel, T. Pleban, H. Vanoss, N. Kedar, H.D. Rabinowitch, and H. Czosnek. 1994. Mapping and introgression of a tomato yellow leaf curl virus tolerance gene, $T y-1$. Theor. Appl. Genet. 88:141-146. 